\title{
Specification A Model for Study of Water Sustainability
}

\author{
Abigail Quezada-Castro* \\ National Autonomous University of Mexico, Mexico
}

Submission: September 28, 2019; Published: October 16, 2019

*Corresponding author: Abigail Quezada-Castro, National Autonomous University of Mexico, Mexico

\section{Abstract}

Background: Theoretical, conceptual and empirical frameworks warn welfare a) the impact of environmental, interpersonal and subjective factors. B) intrapersonal dimensions such as; optimism, commitment, meaning, positivity and achievement as indicators reflecting welfare the association between intra and inter factors such as altruism, affinity, austerity or cooperation.

Objective: Specify a model of relations between welfare dependency reflective, its dimensions and indicators.

Method: Documental study with a selection of sources repositories indexed in Latin America considering the variables of global, national and local context.

Results: The specified model included two hypotheses concerning intra and inter-dimensional inflicted by the alleged correlations between affinity, commitment, optimism, achievement, austerity, positivity, altruism and cooperation.

Discussion: Under the studies of welfare have not addressed the influence of the media in establishing an agenda supply and water rates, it is necessary to include the variable hyperopia, need for information and helplessness in a comprehensive model that explains scenarios public policies, conflict and welfare.

Keywords: Water resources; Availability; Supply shortages; Savings; Welfare

\section{Introduction}

The aim of this study is to specify a model for the study of welfare in terms of water supply in peripheral areas of Iztapalapa, Mexico City (center of the country). A documentary study was conducted with a selection of indexed sources considering the variables determining learned helplessness around tandem water in a locality with low per capita availability. Hypotheses paths dependency relationships between variables from models reported in the literature were established. Finally, the scope and limits specified with respect to the revised model findings were discussed. The model allows the study specified balances and prospective scenarios of water shortages, increased tariffs, subsidies and waivers payment in areas with low rates of human development and high level of welfare.

\section{Water Availability}

Mexico is intermediate in the list of countries with water availability below 1000 cubic meters per capita. Israel is the country with the greatest shortage and Iceland tops the list with a volume of 120,000 cubic meters per capita. The intermediate water availability in Mexico does not inhibit the use of bottles in the case of Mexico City (formerly Federal District) approaches to 353.8 pesos per year per person. This means that, despite having an intermediate availability per person, buying bottled water reflects a shortage in delegations such as Iztapalapa, entity where shortages, food shortages and no water supply is higher than other entities Mexico's capital. In short, the equitable distribution of water seems to be the global, national and mayoral problematic, but the effect of such distribution on the expectations of the inhabitants supposed scenarios such as;

a. Water shortages, policies tandem, spreading conflict and learned helplessness;

b. Lack of provisions, allowances and forgiveness, spreading conflict and welfare;

c. Supply rate increase, spreading conflicts and water comfort [1].

These are scenarios in which the diffusion of scarcity and shortages, subsidies, cancellations or rate increases is illustrated as conflicts between users and authorities that generate despair and welfare citizenship [2].

\section{Welfare Theory}

Theoretical, conceptual and empirical frameworks warn welfare 
a. The context has an impact on the internal and interpersonal in structures of individuals

b. Induction of welfare from domestic and interpersonal strategies change

\section{c. Internal change as a determinant of social welfare}

Although the state of knowledge raises personal welfare and environmental, situational factors is the cognitive structure which regulates external factors and define each stage in human development [3]. It is the case of the theory of lifestyles which formulates six stages of human development predominating birth, growth, exploration, stability, maintenance and decline. Regarding styles of consumption in general and water consumption in particular, the theory of lifestyles argues that regardless of water availability, public policy and media coverage, socialization based on age will determine consumption of water.

In this sense, a teenager who is in an exploratory stage justify their consumption by assuming high availability or low and carry out the steps to consume a greater or lesser extent the amount of water allocated to their locality, residence or person [4-6]. Thus, welfare according to the theory of lifestyles, depends on the stage that society assigns to the individual considering his age and the group to which it belongs or wants to belong. Therefore, a teenager would have a personal wellness if you consume enough water to explore life, emotions, sexuality or reason at the expense of social welfare which provides only a limited amount of water per person.

In a situation of scarcity, shortage and tariff increases, emotional and social welfare it would result in a change process. It is a process in which the dissemination of information, building skills, generating empathy, increased resources and common opportunities and changing systems of community work affect interpersonal and individual changes that anticipate the emotional and social welfare [7]. If welfare is induced, then the factors of positivity, engagement, relationships, meaning and achievement can always determine that the individual establishes the need for change and adoption of a system of strategies to guide their decisions and actions to a common problem as shortage, food shortages or increased tariffs for each volume of water consumption.

From model positivity is built from a shortage and from an abundance of resources; commitment involves monitoring the availability of resources and the expectations of a community; relations refer to negotiations with those who control the resources; the meaning of resources involves hydration or its importance in hygiene; and achievement refers to austerity, optimization, reuse or recycling of water-related products [8].

However, the determinants of welfare have not been linked to the effects of systematic dissemination of news concerning shortages, shortages, tariffs, conflict and participation relating to drinking water.
The theory of agenda welfare, unlike the induced welfare and lifestyles, says that the media disseminate and establish welfare issues provided that they agree to the construction of a media, civil, political and social agenda [9]. In this regard, studies of systematic dissemination of an agenda whose themes are shortages, food shortages, tariffs, conflicts and saving water on the opinions of hearings have shown;

a. Greater persuasion argued scientifically messages

b. An influence that does not change with time

c. An incidence remains constant despite counterarguments

d. An effect that spreads in lifestyles savings [10].

\section{Specification Welfare Model}

From the theoretical, conceptual, empirical and mathematical delimitation it is possible to establish a model for the study linked to the management and use of water resources being. There are two hypotheses concerning the effects of public policies of drinking water inferred from personal and interpersonal factors. Each factor includes four indicators that reflect the impact of the management and administration of drinking water. In the case of the subjective dimension, water problems is taken as an opportunity for those who have an affinity for nature, have developed an optimism about the conservation of natural resources, make a commitment to owning communities the resources and their conservation to ensure the survival of those who suffer or face a high shortage and prolonged shortage of water supply, as well as those who transferred optimization strategies, reuse and recycling of water to the generations of infants and young.

If the individual dimension refers to cognition factors inherent in abstracting information concerning the availability of resources, then the intersubjective dimension refers to factors that explain the associative relationships between users of drinking water. It is a dimension in which aid to those suffering from water shortages and poor quality of it, reveals the positive expectations of a civilian sector and a strategic system of austerity that affects the cooperation around the water supply. The specified model, unlike the welfare model, connects personal capacities and inter-strategies as a response of civil society to public policies and increased rates tandem.

\section{Discussion}

The contribution of this work to the state of knowledge lies in the specification of a model for the study of subjective, community, social, political and economic well-being around the conservation of water resources in areas with high scarcity, shortages, poor health and increased rates. However, the specified model does not address the effect of media on audiences that, in the case of availability per capita, is the incidence of issues concerning lifestyles of comfort and extravagance hegemonic regarding austerity. 
Carreon et al. [11] argue that the decision to support a green campaign depends on the systematic dissemination of water availability and supply alternative candidate. In this sense, the specified model could include the variable need for information as a determinant of the intention to vote in favor of environmental proposals. However, if the campaigns have a bias that places the responsibility to political or partisan adversary, then it can lead to conflicts between supporters of an opposing those who administer the water service proposal [4]. Garcia \& Quintero [5] warn that conflicts not only inhibit the governance of natural resources in general and water resources in particular, but also generates an opposite process to the welfare and helplessness that would be to assume that the environmental problems not they have a solution and that the government's actions regarding environmental protection are insufficient to guide development towards sustainability.

Even the systematic dissemination of natural disasters in the media poses risks and threats that inhibit civil participation and justify inaction [6] or conflicts such as closing avenues, boycotts networks supply, road blockages or sequestration facilities or pipes [12], although farsightedness or inaction justified by the remoteness or likelihood of occurrence of natural disasters and administration corrupt is also a central issue in the entities with shortage and continuous supply shortages [13-16]. Therefore, future research should connect to the specified model with economic, political and social in order to anticipate likely scenarios of scarcity, shortages, suffering or welfare variables.

\section{References}

1. Shaheen Y (2010) The perceived usefulness of information for investment decisions: Evidence from Palestine Securities Exchange Hebron University. Research Journal 5: 283-307.

2. Tekeher S (2013) Mathematics teacher educators and pre - service teacher's beliefs about the use of technology in teaching in African university. International Journal of Innovative Interdisciplinary Research 12: 9-20.
3. Bakabulindi F (2012) Does use of ICT relate with the way it is perceived? Evidence from Mekerere University. International Journal of Computing and ICT Research 6: 75-94.

4. Garcia C, Aguilar J, Rosas F, Carreon J, Hernandez J (2015a) Sociopolitical differences reliability to water conflicts between civilian actors. Invurnus 10(2): 3-13.

5. Garcia C, Carreon J, Quintero M (2015) Dimensions of governance for water sustainability. Peoples and Borders 10(20): 195-203.

6. Garcia C, Carreon J, Bustos J, Hernandez J, Salinas R (2015b) Specifying a communication model of environmental risks to climate change. Entreciencias 3(6): 71-96.

7. Summer L (2011) The Theory of Planned Behavior and the impact of past behavior. International Business \& Economics Research Journal 10: $91-110$.

8. Garcia C, Hernandez J, Carreon J, Mendoza D, Aguilar J (2014b) Specifying a model of social and political agenda on water conflicts and peacekeeping retributive OBETS 9(2): 249-265.

9. Kotaman H (2010) Turkish early childhood educators' sense of teacher efficacy. Education \& Psychology 8: 603-516.

10. Long H (2013) The relationships among learning orientation, market orientation, entrepreneurial orientation, and firm performance. Management Review 20: 37-46.

11. Carreon J, Bustos J, Garcia C, Hernandez J, Mendoza D (2015) Using SPSS and AMOS in a study of environmental thinking and voting intentions in a sample of students. Multi - disciplinarity 20: 73-95.

12. Garcia C, Carreon J, Bustos J, Hernandez J, Aguilar J (2014 $\left.4^{\text {th }}\right)$ A sociopolitical approach to shortages, tariffs, subsidies and tandeos relating to water services. Educational Testing 9(1): 73-98.

13. Garcia C, Carreon J, Hernandez J, Burns J, Aguilar J (2016) Specifying a model of social and political farsightedness. Luna Azul 42: 270-292.

14. Garcia C, Carreon J, Hernandez J, Mejia S, Garcia E (2015c) Towards a water agenda for sustainable local governance. Social Sciences 11(1): 130-154.

15. Simsek A (2011) The relationships between computer anxiety and computer self-efficacy. Contemporary Educational Technology 2: 177187.

16. Yuangion Y (2011) The impact of strong ties on entrepreneurial intention. An empirical study based on the mediating role of self-efficacy. Journal Entrepreneurship 3: 147-158.

This work is licensed under Creative Commons Attribution 4.0 License

DOI: $10.19080 / J Y P .2019 .08 .555733$

\section{Your next submission with Juniper Publishers} will reach you the below assets

- Quality Editorial service

- Swift Peer Review

- Reprints availability

- E-prints Service

- Manuscript Podcast for convenient understanding

- Global attainment for your research

- Manuscript accessibility in different formats ( Pdf, E-pub, Full Text, Audio)

- Unceasing customer service

Track the below URL for one-step submission

https://juniperpublishers.com/online-submission.php 